\title{
On Breaking Up Time, or, Perennialism as Philosophy of History
}

\author{
Bennett Gilbert \\ Portland State University \\ bbg2@pdx.edu
}

\begin{abstract}
Current and recent philosophy of history contemplates a deep change in fundamental notions of the presence of the past. This is called breaking up time. The chief value for this change is enhancing the moral reach of historical research and writing. However, the materialist view of reality that most historians hold cannot support this approach. The origin of the notion in the thought of Walter Benjamin is suggested. I propose a neo-idealist approach called perennialism, centered on recurrent moral dilemmas and choices. This suggests a view of the relations of moral thought and ontology placed in the diachronic context that historians study.
\end{abstract}

\section{Keywords}

materialism - idealism - ontology - justice - Benjamin Bevernage - perennialism historicity - moral

For Nasser Hussain (1968-2015),

Professor of Law, Jurisprudence, and Social Thought, Amherst College. 
An increasingly large and consequential literature in the philosophy of history has been developing the consequences of the idea that history as understood in Western thought from early modernity and especially as practiced by those who write about history from the early nineteenth century onwards is at an end. It is not of course past-ness that is at an end, for matters continually pass away just as they come to be. Rather, the claim is that the relationship to the historical past as conceived up until recently is at an end and is in train of its successor. It has been called the end of a "regime of historicity," also sometimes called a chronotype. The literature I refer to attempts to apply this concept to the issues of human self-understanding to which it points future historical theory.

Because this part of current philosophy of history is concerned with the temporality of human existence, it takes on issues of ontology. By ontology I mean philosophical reflection on the categories and nature of being. By moral philosophy I mean philosophical reflection on the good by means of examining moral dilemma, choices, and obligations. The work of historians has always been a moral project, but ontology and moral philosophy cross in the current historical-theoretical situation with consequences that I shall try to bring forward. The territory in which these consequences appear is first of all the agonism between materialist ontology, taken as the notion that reality consists solely of physical matter and physical forces, and idealist ontology, taken as the notion that reality either fundamentally or entirely comprises non-physical substances or spiritual entities or a combination of these; and by extension is also some of the attempts to settle this struggle that apply to the theoretical problematic of history. ${ }^{1}$

The approach to this project to which I address this paper is the notion of breaking up time, which I will also call time-breaking. The proximate first promoter of time-breaking is Walter Benjamin, a part of whose notion of it I will

1 In what follows I use "materialism" and "materialist-realism" to refer equally to the same thing, materialist ontology. Materialism and idealism form a reasonably stable and symmetrical binary, despite all the many versions of each. However, realism and idealism are not a symmetrical pair: while there are non-materialist realisms, there is no materialist idealism. The word "idealism" therefore must do double duty, standing against both the non-materialist realism that opposes materialist ontology - as idealism itself does - and the materialist realism that both idealism and non-materialist realism oppose. 
discuss below. ${ }^{2}$ Breaking up time is the claim that linear time on the rational model that Western thought has created during and for the now-ending era of historical consciousness, can and ought to be replaced by a theory in which the past, instead of breaking off from the present "like an icicle," persists really and substantially (in some sense of these qualifiers). Historical time, then, is not periodized and put to rest, its movement is not "progressivist," and the historian is not a "distant, impartial observer." Chris Lorenz and Berber Bevernage laid out this territory (and catalogued its literature) in full in their introduction to the anthology they edited called Breaking Up Time. ${ }^{4}$

Of the various historical-theoretical directions they map out I shall address just one because it is the one that in my view strikes at the heart of the matter. This is the argument for time-breaking as reparative justice, forcefully made by Berber Bevernage in his History, Memory, and State-Sponsored Violence. ${ }^{5}$ The goal of the argument is strong and valid. But it exposes a problem running through much of the literature on the changing chronotype: that it is based on a materialist-realist ontology, which cannot accommodate time-breaking. To this difficulty I will propose a repair based on the diachronic dimension of moral philosophy.

My solution to this is perennialism as an approach to understanding meaning in historical time. ${ }^{6}$ To some extent it is a fitting addition to the ways in which Helge Jordheim has developed rejection of periodization towards a new view of tensed time. ${ }^{7}$ It also can be consistent with some of the aims of the French

2 Marek Tamm (citing Georges Didi-Huberman) in his introduction to Afterlife of Events: Perspectives on Mnemohistory (Hampshire: Palgrave Macmillan, 2015), 9-10, regards Aby Warburg along with Benjamin as an initiator of theories of Nachleben, "the persistent past."

3 Berber Bevernage and Chris Lorenz, eds., Breaking up Time Negotiating the Borders Between Present, Past and Future (Göttingen: Vandenhoek and Ruprecht, 2013), 10.

4 See note 2.

5 London: Routledge 2012.

6 I do not directly address the metaphysics of time in this paper. But it is worth stating for the record that, as a number of people have said, it is well worth investigating within philosophy of history, which habitually sets it aside. Work in analytic metaphysics, which may be said to have begun in David K. Lewis's theory of time, has very much increased the importance of the subject for thinking about history. Bevernage and Lorenz (Breaking Up Time, 13, 17, et passim)suggests that philosophers of history should pursue the metaphysics of time, though they shy away from it because of its famously intractable puzzles and obscure relations to historiography, in order to support more morally acceptable theory.

7 See his two related explorations of Koselleck's theory of temporality: "Against Periodization: Koselleck's Theory of Multiple Temporalities," History and Theory, vol. $5^{1}$ (May, 2012): 151-171; and "Does Conceptual History Really Need a Theory of Historical Times?," Contributions to The History of Concepts, vol. 6, no. 2 (Winter, 2011): 21-41. 
schools of sociology of knowledge that endeavored to find a way to re-insert human meaning into empirically valid sciences. ${ }^{8}$ But there are other respects in which the perennialist notion is exogenous to recent theory discourse. Perennialist theory of history accounts for historical events, and likewise the activity of historians, as forms of deliberation by moral agents on moral dilemmas that run, though at varying levels of urgency at various times, through all human existence. After discussing the problems in the historical-theoretic of time-breaking to which perennialism is offered as a helpful response, I will return to perennialism and its connection to idealist ontology in the final section of this paper.

The notion of time-breaking in current advanced philosophy of history is based on the position that the experience of history as established up to the present era is at an end. This "experience of history" is here meant to include (1). the construal of the human past as a source of authority, (2). the common view that the present in human experience is an advance over the past in empirical knowledge and technology, and (3). the broad run of historiographic thought and practice from c. $1800-1820$ to the present. ${ }^{9}$ Koselleck uses his analysis of historical self-consciousness to establish this; others use the markers of globalization or the anthropocene, and still others use the progress of networked information. These and other approaches are descriptive - that is, they attempt to give a veridical theoretical account of a long historical movement, affecting consciousness, society, and knowledge, that actually took place and is taking place in the real, external world of human activity and also in performances by historians within that world. The theory of historicity also urges great changes

8 As François Dosse in Empire of Meaning: The Humanization of the Social Sciences, translated by Hassan Melehy (Minneapolis: University of Minnesota Press,1999) (L'empire du sens, 1995) shows, much of French philosophical sociology of the last half-century has endeavoured to do this through thinking about history and time.

9 Reinhard Koselleck puts the beginning of "history" in the late Enlightenment, while Peter Sloterdijk says it began with Columbus's launch in 1492 or with Magellan's circumnavigation in 1518. In so far as one must set dates, I suggest for the earliest date the deployment of printing technologies in c. $1375^{-1450}$ as the best choice; and for the more proximate turn to modernity I suggest, following many historians of science, the privileging of linear time over stable time when the steam engine replaced the balance wheel as the most important engine c. 1820-1840. All these agree, however, that it is by now at an ending variously set at 1945 or 1968 or thereabouts. 
of behavior, especially by historians. But it is not the necessities of actual conditions that are held to justify the various prescriptions consequent to these theories. These philosophers are deeply involved in the most important existential and moral issues of this era. Of course, they recommend what they think will yield more truthful historiography because truth is a good. But they also prescribe with moral force towards the great moral causes of these times, the generation of which historians study and in which historians have often been not innocently complicit. In three words these causes are human survival, peace, and justice. In the end, because a moral case is more persuasive and motivating than a descriptive claim that an urgent change is under way, one must address the moral argument in any theory. ${ }^{10}$

Berber Bevernage in his History, Memory, and State-Sponsored Violence gives the argument en chef for breaking up time: that the obligation to pursue justice requires us to reject linear notions of time. ${ }^{11}$ The irreversibility of time, he argues, leads people to understand history as so distant that one cannot establish any "time of jurisdiction" in which to institute justice for past wrongs; it is "anti-moral."12 To the extent that we view past-ness and present-ness as mutually exclusive, his argument proceeds just as if the one is dead and the other is living, and we shall also hold injustice in past events to be irremediable. ${ }^{13}$ If a point of view undercuts justice, we must reject it, for we must have justice. If we take the past to be so fully determining that we cannot have agency sufficiently free as to be capable of changing the past far enough to redress injustice, then we must re-consider in what ways past-ness is bound and determined - to reconsider existence itself in time. Moral obligation in general requires an assertive, capable agency in this sense rather than utter submission to determination; and so this general principle presses onto our notions of history and onto historiographic activity. Linear time thus becomes a moral crisis.

This situation is the opposite of that which Kant thought was to come to pass, which I take here as an exemplar of progressivist views of modern history. For Kant his own proof that our autonomy is rational and necessary proves also

10 The notions of moral life I have in mind throughout this paper include the largely pragmatist view that it is a communicative deliberation in both individual and corporate actors ans a further view that it chiefly concerns the experience of obligation rather than production, claims, arguments, and prescriptions of moral values.

11 The mattes discussed below are a just one part of Bevernage's book and of his case, which both takes transitional justice as the model, examining recent cases with great penetration, and develops many further philosophical considerations.

12 Bevernage, History, 2-3, 168.

13 Bevernage, History, $\mathrm{x}, 1-2$. 
that progress through time will follow the ameliorating path of improving reason. In his various essays on philosophy of history Kant found that an acceptable notion of society must include the possibility of moral improvement, or enlightenment. We can, Kant argued, understand the possibility really to exist despite all the determinations and limits of the spatio-temporal world because $q u \bar{a}$ possibility it is not a route past finitude or into the noumenal but instead is the locus of our freedom in the world of reason. ${ }^{14}$ Nonetheless, despite its appeal, this claim - composed of definitions of possibility and actuality that are matched for the convenience of this pleasing claim - has no probative content. It is aspirational rather than entailed: we do not quite know what it is that is phenomenal but free enough to make moral choices according to some normativity worthy of the name of conscience. Coming out of two centuries' attempts to explore what Kant calls the possibility of enlightenment we again stand, by thinking through the argument for time-breaking, at the portal of the antinomy of free and determined human will.

Bevernage argues that the linear forward progressive time that Kant posits is the problem. It became a petrifying skull's gaze, freezing us into submission rather than endowing us with powerful moral agency. Kant's hope became that which deprives us of hope. In order to break the jam-up, the argument against the binary of past and present, having rejected the time of progress as deployed during the last two centuries, requires those who seek justice to re-conceive time; and the suitability of this re-conceived breakable time must stand as proof of its veridicality - of its being a truer account of the reality of time than the hopeful, enlightening, progressing linear time that perpetuates the binary of free and determined moral will.

From this principle Bevernage directs us in his book to at least two consequences. First, as a practical matter (a). those holding such a view block themselves out of the conviction that they have power to remedy injustice and also (b). bad actors wishing to defend the agents of past injustices from remediation use past-ness to defend against attempts at rectification. ${ }^{15}$ This is virtually irrefutable, for in so far as we hold past and present as far apart as the death and life we cannot mix them. If indeed it is a matter of binary definitions it

14 Carr, Experience, 90-91, along with others, sees this first view of society as a progressive entity formulated by Kant as the beginning of what we have come to call history. Alan Megill, "Is There Moral Progress in History? The Old Kantian Question Raised Again," in British Abolitionism and the Question of Moral Progress in History, edited by Donald A. Yerxa, 154-162 (Columbia, sc: University of South Carolina Press, 2012), surveys Kant's interest in moral progress in history.

15 Bevernage, History, 9-16.

JOURNAL OF THE PHILOSOPHY OF HISTORY 12 (2018) 5-26 
might be only trivially true. But the claim is true also on wider grounds. If the past is only and merely deceased, then one (in any present) has no reason not to regard it as other than a group of intrinsically valueless mental and material objects. In this vacuum of regard, one is free to take these objects as entirely plastic, to be mixed and matched according to mood, or as commodities by which to gain some thrill in the marketplace of alienation, or to extract from their use the pleasures of desecrating the dead and of spectacularizing the lostness of one's own era.

But the impulse of moral obligation and the long experiences we have of it instruct us, in so far as we accept the restraint of moral obligation upon our thinking and behavior, to find a firmer foundation for this once we notice the difficulties posed by the idea of the past. To say only that we are free to do more than merely appropriate the past - that it does not merely seem that there need be no reason we cannot punish or redress despite the past-ness of the act under judgment - still seems to take the past as dead enough to ignore or address at will. Bevernage's claim must have the wider ground of moral obligation to support it if it is to be more than trivially true. When we claim that the past is really not dead but is revenant, that it can haunt as - as Bevernage does following Derrida's notion of the "hauntology" of the ghostly past - there must be a strong notion of moral obligation to support the metaphors of ghosting and haunting. It is these deeper difficulties of connecting moral life to time to which Bevernage wishes to draw our attention in order to press the necessity and value of arguing it through, firmly founding a notion of justice.

The second consequence of Bevernage's position is that the principle of jurisdiction over the past is held to be a truthful corrective to historiography, which itself is at a crisis because the normative notion of time with which historians have worked is at an end. ${ }^{16}$ It is a positivity in the worst senses; oppressive forces rely upon it. Its linearity is now toxic. And the lesson is not solely for historians, since in so far as each person is a moral actor, each has a relationship to the past. Each person is a kind of historian, and historians are moral actors. Leaving our commitment to justice at the mercy of the power of words - at the consequences of cleaving past and present so decisively that the living forget the dead - is morally unacceptable. We come again to the crossing of moral and ontological considerations about time.

But what has been said so far directs us to a third consequence of the contention that we must break up linear time: what metaphysics can afford to break up time? The moral demand to break up linear time requires this, but would such metaphysics bring unacceptable consequences in areas that, although

16 Bevernage, History, 108-110. 
not directly moral, will inescapably adversely affect the notions of morality and justice available to us? This potential for the ontological to change the moral - enhancing it or undermining it - comes from the actual pull toward ontology that moral obligation exerts on thought by demanding full, ultimate grounding in the nature of existence, by settling for or stopping at nothing less, by so exigently urging us to protect and nourish it that honesty compels us to pursue it to its source. Moral problems present the worries that ignite the philosopher to follow thought through the whole range of reason, and it is often the business end of ontology. If moral life is not merely a matter of words but is instead a matter of existence, then moral philosophy has always the task of making peace with foundational ontology. ${ }^{17}$

With these three consequences we see three areas of inquiry come together at the notion of breaking up time, each bringing its powerful motive for philosophical thought. The first is that of personal human agency sufficient for strong action towards the good and for justice. The second is writing history, especially a portion of the many desires that cause people to write history. And the third is the ontological commitments by which we can shape and justify positions in the first two matters. Bevernage is not alone in coming to this crux. Lorenz, Eelco Runia, ${ }^{18}$ and Frank Ankersmit, ${ }^{19}$ joined by David Carr from the angle of phenomenology, ${ }^{20}$ work to develop a morally infused, justiceseeking, and culture-advancing theory of history by disestablishing the opposition of past-ness and presence. They attempt to realize the moral growth in Kant's zone of the possibility of enlightenment while avoiding the positivist deadening of the past and the "progessivist" sacrifice of redemption for the sake of the future. ${ }^{21}$

If my words here suggest that the historical-theoretic bends ontology to meet moral needs, I do not write them as a criticism. What makes ontology right in my view is its moral effect; the correctness of an ontology just is its offering the

17 The idea of confronting ontology and morality with one another in an agonistic relationship has its proximate origins in Kierkegaard and Levinas. Levinas takes ontology to be "a philosophy of power." But morality demands something else: "... ontology before metaphysics is freedom ... before justice.... The terms must be reversed" (Totality and Infinity, translated by Alphonso Lingis [Pittsburgh: Duquesne University Press, 2007], 46-47).

18 Notably in his "Presence" History and Theory, vol. 45, no. 1 (Feb., 2006): 1-29; and Moved by the Past: Discontinuity and Historical Mutation (New York: Columbia University Press, 2014).

19 Notably his Sublime Historical Experience (Stanford: Stanford University Press, 2005).

20 Especially his recent book, Experience and History: Phenomenological Perspectives on the Historical World (New York: Oxford University Press, 2014).

21 Bevernage and Lorenz, Breaking Up Time, 14-15. 
path of logic in support of the good - "hunting the Good," Plato called it ${ }^{22}$ - in so far as it does so, because logical correctness is not more important than moral life, than compassion for others, than doing the next right thing. Now deference to ontology has its own force, that of entailment and necessity, since we are obliged to be logical if we do not wish to fool ourselves. Yet from the same desire for rigorous honesty we have come to fear the destruction consequent to the impulse of logic towards organization, efficiency, and speed, and away from people and away from compassion - especially now, in a period in which acceleration, by rapid and unquiet disruption, is a prevailing feature of the progression of knowledge, technology, and socio-economic organization. From this arises a strong motive for reversing the submission of ethics to ontology and to replace this, not by a reverse dominative power, but with an approach to ontology that can support ethical theory - whether based on rules, results, or virtue - rather than contradict or undermine it. The product of this desire is for us inexactly known, either as metaphysics and as ideology or social formation. No one knows how fully to square the two, in the end, especially if fideistic "knowing" outside a secular framework is not held to be acceptable. The reason that time-breaking "gets to the heart of the matter," as I put it in the first section of this paper, is that, as I understand it, it re-arranges (or re-defines) diachronesis in response to moral force by preferring this moral force to the system of power that ratio spins out from logical necessity.

One must take this position, or something very much like it, in order to take ontology seriously in moral philosophy and therefore in theory of history, for history-writing has moral and ontological wings embedded in the higher-order commitments of historians. This is not an unperilous position to hold. For one thing, among many difficulties, it depends upon regarding human moral capability as a thing other than natural material forces, at least in part. ${ }^{23}$ But without such a position with regard to the mutual deference of moral philosophy and metaphysics, the intersection of moral agency, history, and fundamental philosophy cannot succeed due in some cases to an excess of ontology and in other cases to a deficit of it. My reflection on time-breaking aims therefore towards choosing, since we must choose, what ontology and what measure of it supports moral obligation. Time-breaking as we have it up to this point has, having focused on time, retains a problem in its ontology that must be cleared up in order to give time-breaking requisite moral purchase.

\footnotetext{
22 Philebus 65 a1.

23 Here I deliberately echo an idealist reading Vico's distinction between the human and the natural.
} 
To support their moral concern some philosophers of history reject linear time on grounds resultant from an analysis of historical discourse. Hayden White contributed to this line of thought by his attempt to prove that historiography is not veridical. It is, instead, he argued, narrative - that is, a kind of persuasive endeavor for which factuality is not only not the chief concern but also is not a goal it is capable of achieving. While they do attend to the facts, all historical accounts use language - even when indirectly as for example when the historical account is a painting - which, in turn, gives the historian the great powers of rhetorical figures and schemes, of tropes, of metaphor itself, and of narrative grown out of the practices of authors of fiction as well as of historians. White holds that historical accounts are stories, founded in the imagination, articulated by rhetoric, and invented by human persons to explain our history rather than to recounts facts. This is fitting and good, the narrativist argues, because historiography is not history, things no longer extant being of course not present; rather, it is the presentation now of the thoughts of those who thought and acted in the past as re-constructed by the class of scholars working at this necessary and beneficial task in the good conscience of honesty and with due regard for factual truth. ${ }^{24}$

Against this particular turn of the screw of "the linguistic turn" Ankersmit and then Runia, Lorenz, and Bevernage, as well as Carr and Hans Ulrich Gumbrecht, propose a sense of the presence of the past that is independent of verifiability or falsifiability because it is based on a notion of real-material existence - materialist though freed of positivism - that responds to a broad range of human needs, desires, motives, and wisdom, including what I here call moral life. Lorenz has argued that the claim that historiography is narrative (or, more broadly, "fictional") is as trapped in the limits of crude positivism as is the claim that history is nothing but chronicled facts. ${ }^{25}$ Carr also argues this position and works the argument hard enough to drive it into the basic phenomenology he proposes for historical time. Ankersmit calls the alternative "sublime historical experience"; Gumbrecht says it is metonymy rather than metaphor, presence rather than interpretation; ${ }^{26}$ and Runia describes

24 Chiel van den Akker, "The Exemplification Theory of History: Narrativist Philosophy and the Autonomy of History," in Journal of the Philosophy of History, vol. 6 (2012): 236-257, expresses this thought as "the autonomy of history," by which he means the historian's power to shape the past.

25 "Can Histories Be True? Narrativism, Positivism, and the 'Metaphorical Turn,'” History and Theory, vol. 37, no. 3 (October 1998): 309-329.

26 Production of Presence: What Meaning Cannot Convey (Stanford: Stanford University Press, 2004). 
historical presence as a way of responding to the traumas that comprise human history. It is this presence, taking the shape of narrativity understood as a part of human ontology, that breaks up the linear, progressive time of positivities. The phenomenological and other analyses that support these views are, as I see them, moral at their fundament. They share the project of advancing a more morally responsible ontology than the destructive one now widely associated with other metaphysics. Viewing matters in this way is not to reduce them to illocutions or to ignore their detailed logic. My aim is just the opposite. I agree with them in their moral inspiration, for the risks to all humankind are certain. After addressing the problem with this approach I will return to the matter of how best to support time-breaking through ontology.

\section{III}

Walter Benjamin's 1940 essay "On the Concept of History" ("Ober den Begriff der Geschichte"), usually referred to in English as "Theses on the Philosophy of History", is one of the sources of the notion of breaking up time, notably its famous section xvii:

[Historical] Thinking involves not only the flow of thoughts, but their arrest as well. Where thinking suddenly stops in a configuration pregnant with tensions, it gives that configuration a shock, by which it cristallizes $[s i c]$ into a monad. A historical materialist approaches a historical subject only where he encounters it as a monad. In this structure he recognizes the sign of a Messianic cessation of happening, or, put differently, a revolutionary chance in the fight for the oppressed past. He takes cognizance of it in order to blast a specific era out of the homogenous course of history - blasting a specific life out of the era or a specific work out of the lifework. As a result of this method the lifework is preserved in this work and at the same time canceled; in the lifework, the era; and in the era, the entire course of history. The nourishing fruit of the historically understood contains time as a precious but tasteless seed. ${ }^{27}$ translations are becoming standard in English."Theses” is in Walter Benjamin: Selected Writings, Volume 4: 1938-1940, edited by Howard Eiland (Cambridge: Harvard University Press, 2003), 401-424. The German text is in the Gesammelte Schriften 1.2.691-706. The ideas Benjamin uses in this passage have deep roots in his philosophy and properly ought 
This paragraph is probably the most widely quoted and influential text in twentieth century philosophy of history. It stands as a locus classicus for a way of conceiving of history writing as interpretation. We change the past by interpreting it because the past exists only in our accounts of it. That past events do not exist except as presently understood is sufficient warrant for claiming that history writing is interpretation rather than a molar heap of facts. This is readily agreed to by all, but beyond this a final understanding of this passage is a kind of unicorn. The reason is that Benjamin claims something more than mere interpretation: the power of the historian to stimulate moral obligation out of a certain way of interpretation. This claim leads to difficulties reflected by many readings of Benjamin's theory of history - due to the issues I shall describe.

Benjamin presents a philosophical history that he hopes the conventional notion of chronological history does not confine but is nonetheless materialist in ontology by virtue of obedience to the chronology of causal regularity. His "philosophical" addition to material causality is a vision of far-reaching amelioration of human suffering. As this must needs take place in the future, Benjamin's problem is to find a force working in the past that will make this result possible. Any determining causality within history that might reconcile causality and contingency is, Benjamin establishes, an ideal concept without material existence and hence without the material reality that gives predictive value to statements. This then is a difficult situation: do our drives and desires for the good have the power to effect our escape from the reality-driven, downhill-running rubble avalanche that human experience seems inevitably to be?

To answer this puzzle Benjamin here gives us messiah or, more precisely, "a weak messianic power" that humans hold. In Biblical history the messiah was an answer to problems of society-wide moral turpitude that neither patriarchs nor prophet nor judges nor kings could solve. Each time one of these types of authoritative leader restored moral well-being and godliness to the Israelite tribes for a while following the harmful decay, yet another decadence followed until finally the Temple was destroyed. Over time some Israelite communities

to be considered in that complicated context. The problem I discuss in this paper can be applied to his other efforts, but at the same time it is by no means adequate to their subtlety and power. I use this passage as a locus classicus for an idea now controverted in other forms and therefore cite no other texts by Benjamin either in support of or to criricize my position, although both are available. One cannot regard the "Theses" as his fullest statement of theory of history; one must include The Arcades Project, especially Konvolut N, and Berlin Childhood as parts of his philosophy of history. 
concluded from this pattern that if humankind has a moral constitution existentially tied to God, then God will at some time repair what had hitherto been repeatedly irreparable on a permanent basis. This repair is messiah. ${ }^{28}$

Yet if historical events (tragic or not) are fully and truly explained by material causes - that is, if they are caused by natural causes and are intelligible to us only through a materialist ontology, as Benjamin does hold - it follows that for messianic power to be intelligible it must interrupt or over-ride material, or natural, causality. Can we properly conceive of a force of a type of action that both follows the natural causal order of time and also re-arranges it? Benjamin did not accept a historiosophy such as the author or authors of Exodus, Deuteronomy, and the books of Judges, Samuel, and Kings assert; he did not believe in divine intervention in time any more than he believed in final cause immanent in a material universe. As opposed to immanent final cause, the monad as conceived in this passage is a human and material consciousness that can "break up" time in some sense of these words. This sense of "breaking up" must signify the actions of human conscientious will in the world that efficient material causality makes. It must therefore meet two conditions: the human part must be considered to operate with sufficient strength against the historical processes of material causes, and material causes must be considered to be sufficiently valent in historical processes to account for reality without supposing any immaterial entities or forces. If these two conditions were matters of mere words, the definitions of the terms human agency and material causes could be adjusted to avoid contradiction. But historical processes are not simply words. To the materialist and to everyone else as well they have just exactly the kind of reality we cannot talk our way out of. To such a thinker Benjamin's theory is "merely" a specimen of metalepsis. Does the metaphor of breaking up, like the words "interrupt" and "step over" I used at the top of this paragraph, denote something that can be deemed real within materialist ontology? Or can it be considered real only within some other kind of ontology?

28 Benjamin might have been affected in some way by an interesting concept recently noted in the illustrations to some medieval Jewish manuscripts: that future messianic redemption is present in some form in events preceding it as "imminent delayed action." See Marc Michael Epstein, "Thought Crime: implied ensuing action in medieval manuscripts made for Jewish patrons and audiences," in Manuscripta Illuminata. Approaches to Understanding Medieval \& Renaissance Manuscripts, edited by Colum Hourihane, 72-86 (Princeton: Princeton University Press in association with Penn State University Press, 2014). It is very likely that Jewish religious thought influenced Benjamin in any number of ways, but throughout his adult life he clearly adhered to a non-religious path. 
On the understanding that it is desirable to bring time-breaking to good account, one must proceed from one of these two choices: that the activity of breaking is either an intervention in before-and-after causality or that it is a decision to adjust our thinking to the fact that time is already "broken up" that is, that before-and-after temporality is not a true description of historical time. As to the first of these choices, we human persons clearly have no power to reverse phenomenally apparent causality, even though we can see that effects are present in some way in causes and that causes persist in some way in effects. As to the second choice, if time is broken in this way it does not constitute material reality. Materialist ontology holds that matter alone exists. Arresting thoughts, blasting life out of the past, both preserving and cancelling events - the language Benjamin uses - are powerless idealist fancies if one sees the world as material, no matter how great the limits to our understanding of material historical processes one insists upon.

This argument I have just made subjects time-breaking, both in Benjamin and in his successors in this matter, to a very rigid realist logic - a materialism ferox. Why could we not simply hold the past to be a positivity in one regard and an ideality or a internal entity in another? As Lorenz and Carr point out, one cannot have a positivist onto-epistemology and at the same time hold a de-constructed view of historical narratives. Materialist-realist ontology offers no modulation in commitment to its notion of veridicality if it is to be taken seriously. Empirical facts work: by using them we keep the water we drink safe and the bridges we build remain standing. From a materialist point of view "facts" in the past are subject to the same constraints. We can make sense of them if and only if we establish causal succession among them. So brokenup time as a notion of historical agency in one aspect entirely natural and in another aspect an immanent non-natural thing is not acceptable if one is committed to a materialist and realist ontology.

It might well seem strange to bludgeon Benjamin with the materialism ferox that is the frost-bitten logic he desired to escape and an oppression he aimed to lift. ${ }^{29}$ The work of Ankersmit, Bevernage, Carr, Lorenz, Runia, and

29 Stéphane Mosès, in The Angel of History: Rosenzweig, Benjamin, Scholem, (Stanford: Stanford University Press, 2009) (L'Ange de l'histoire, 1992) upon considering Benjamin's links to Jewish messianism holds that Benjamin's notion of temporality rejects causal continuity in history. I do not think that is correct, but in any case my discussion concerns the persistence of materialist realism among philosophers of history who are interested in the current themes described above. As I say above, I am using this text as an exemplum. In Arcades Kon. N 49 Benjamin does set past-to-present time as mere succession of events (i.e., causality) over against their combination in dialectical understanding as 
others takes up phenomenology, de-construction, trauma psychology, and other theories in order to developing notions of history that do not end in the binaries and antinomies of earlier ontologies. And, as I argue, getting the ontology right - in this case, as a fully consistent view of time as successive intervals created by materially caused events - is less important than moral life, than compassion for others, than doing the next right thing. No one wants to say on either moral or logical grounds that it is impossible to imagine states of affairs, such as the just reconciliation of past or present wrongs or a better future for humankind, that are not currently the case.

Speaking more generally, materialist-realist ontology, even in any one of a number of forms that seek to soften the pure doctrine, must exclude compromise ontologies that do not rely on mimetic recollections and representations of experience by thought. Benjamin in fact recognized this when he rejected positivist historicism and developed a method that worked through fragments rather than through continuities. Discontinuities do of course fit into non-ideal views, for nothing is messier than lived life. Historians who work with methodologies of particularization prove this all the time. Nevertheless, in order to fit thought to experience, materialist realism requires thought to find pattern (or lawfulness) in experience; and, just because it holds experience to be separate from thought, it must spur thought to catch up to experience - to seek pattern to an ever-higher degree. The inner tendency of realism favors logic over context, evaluation over understanding, structure over reconstruction, and nomos over bios. If one wishes to "break up" time in the philosophy of history, whether for meliorist purposes or for any other purpose, materialist ontology has to give way. If it does not give way, a strong materialist and determinist causality holds tensed time in conventional ontological and moral position.

Thorough-going materialism dominates the kind of philosophical realism that most historians adopt. On this basis they must deny the possibility and the reality of more than one valid kind of knowledge, that of material events.

\footnotetext{
"Then" and "Now," giving them a mental (but not immaterial) status. Some other important commentary on this idea includes: Walter Richter, Walter Benjamin and the Corpus of Autobiography (Detroit: Wayne State University Press, 2000), 38-40, on the non-mimetic historicization of the modern subject; Peter Szondi, Satz und Gegensatz; sechs Essays (Frankfurt am Main: Insel-Verlag, 1964), 284-288, describing Benjamin's open-ended future, more like the future-perfect rather than the perfect tense; and, most recently, Sigrid Weigel, Die Kreatur, das Heilige, die Bilder (Frankfurt am Main: S. Fischer, 2008), 37-41 (in English as Walter Benjamin: images, the creaturely, and the holy [Stanford: Stanford University Press, 2013]), which, exploring Benjamin's interest in Freud, reads his theory of non-mimetic history through Freud's understanding of the functions of memory in the unconscious and the conscious.
} 
It was upon precisely the opposite position - that humans have a knowledge of human history different in at least one critical respect from any other kind of knowledge (though similar to mathematical knowledge) - that Vico set philosophy of history; and it is against this that materialist realism must hold, as Stephen Gaukroger puts it in his critique of Vico's conception of historical knowledge, that we simply need no other kind of knowledge. ${ }^{30}$ Other more yielding theories of realism do exist. ${ }^{31}$ Phenomenology is such an approach, as it is a non-materialist realism. By analyzing impression, retention, recollection, and protension as modes of all types of human awareness, it sees time as moving in many directions through all the complexities and contradictions of consciousness. So also American Pragmatism aims to protect the multiplicity of human existence from crude reduction. But the issue at stake here is not, what weak realism might make for a successful light materialism. It is, rather, to argue that the logic of materialism, based on the successes of scientific method, reveals an urgent and implacable fracture within the moral commitments that time-breaking claims. Phenomenology and pragmatism do not have to justify moral obligations, but they are tools in the toolbox for a moral basis in breaking up time because they center on human consciousness and are best developed as forms of idealism.

But if and when they are employed as a non-idealist ontology in the end they do not then help to provide the alternative account of time-breaking that I claim is necessary. For example, Hilary Putnam's demolition of the fact-value distinction relies on modalities in ordinary language, which then are judged useful or not useful according to concrete - and historical - circumstances. ${ }^{32}$ This has force, though it does not well describe how we go about making values out of the historical and memorial experience. But for the materialist historian claims about the past are either physically true or physically false. Under this view, the thoughts or uttered possibilities of historical actors are so particularized by language and all other causal circumstances that they cannot speak to us except through the detailed labor of empirically-based and materially accurate reconstruction, which is supposed necessarily to exclude our sentiments.

\footnotetext{
30 Stephen Gaukroger, "Vico and the Maker's Knowledge Principle," History of Philosophy Quarterly, vol. 3, no. 1 (January, 1986): 29-44.

31 There are also less yielding materialist realisms, such as that of Alain Badiou.

32 Hilary Putnam, The Collapse of the Fact/Value Distinction (Cambridge: Harvard University Press, 2002) and Ethics Without Ontology (Cambridge: Harvard University Press, 2002). Robert Brandom follows him in this line of thought; both approaches are largely based in renewed American Pragmatism.
} 
Another example is Speculative Realism - currently a most glamorous sensibility in resistance to materialism ferox - which is meant to be more yielding, but when push comes to shove it is not. Its case is that idealism taints phenomenology; and, firm in its rejection of the supernatural, it must and does hold that our only good option is materialist-realist. Yet if Speculative Realism claims materialism - that there can be no identity of mind and the world of the idealist sort - it must also hold that language does not disclose being and that we cannot re-enchant, no matter how marvelous the nouns or deep the metaphors or clever the discourse or strategic the philosophical critique.

Time-breaking cannot be materialist if it is meant to be moral and an instrument of justice; and whatever possibilities there might be for materialism in historiography, breaking up time must be quite another kind of theory. We cannot, without a non-materialist account of moral obligation, re-inhabit the past or seek its authorization of our principles or hopes. Time-breaking does seek this just because its theorists know, as Benjamin did, the fatal stress that materialism puts upon hope. Nonetheless, no empirical way of proving the nonmaterial exists. Nothing replaces the force of faith.

A more yielding kind of idealism also is necessary; and this, I think, is available. Another way to put the problem of pure and strict ontologies, impenetrable solids at war with each other, ${ }^{33}$ is to put it in terms of risk. If we take the road of strict idealism, we run the risk of unleashing a flood of obscurantism. If we take the road of strict realism, we run the risk of having no resources for moral deliberation. In so far as the writing of history is a moral endeavor, as well as a project concerned with material causality, its theory cannot be materialist because materialist-realism gives no ground on which to break up time in order to conceive of or institute justice.

\section{IV}

In the model of time-breaking from which current endeavors descend, Benjamin's dialectical image, a trace, flashes up, intersects, interrupts, capturing the present in its illumination. Thus re-configuring the flow of conventional

33 The anthropologist Eduardo Viveiros de Castro uses these phrases, which is related to ideas from Michel Serres and Bruno Latour as well as others, that an ontology is a war machine - a description he means quite literally - and that ontologies are like impenetrable solids bumping into one another in his fascinating essay "Who is Afraid of the Ontological Wolf? Some Comments on an Ongoing Anthropological Debate," (2014), online at: https://www.academia.edu/12865685/Who_is_afraid_of_the_ontological_wolf. 
historicist (or "progressivist") time in consciousness, it must obtain (if it is to obtain at all) in a domain different in some profound way from that of the material world set in determinate diachronic natural processes. Materialist realism, on the other hand, must be governed by a rigid inner necessity that causes it to retreat from compatibility with other points of view and to return to its founding elimination of alternatives. Idealism of course can take its own mirrored form of this, and its doing so took the form of absolute idealism. The conventional opinion today is that rejection of absolute idealism is rejection of idealism altogether, except when "idealism" is construed as including constructivism by materialists favoring some version of constructivism. But idealism minimally is non-materialist ontology. Since time-breaking must rest on something other than materialism, it can rest instead on non-absolute idealism, or, to use a broad term, neo-idealism. ${ }^{34}$

Certainly some deep and broad enrichment of human consciousness of its own experience and of the cosmos, a powerful phase of the ongoing transformations of communication and knowledge, is under way. This new historicity must at the minimum move from the historicity fully imbricated in material causality, with which we are familiar through materialist realism - the very term that now for us is limiting or even oppressive. In other words, if historicity is changing, so too historiography based on materialist-realist causality must change. The power of breaking up time that we value is its power to interrupt and alter that kind of causality: to re-direct our horizon towards the future through the past. To do so it requires and provokes our move to a different temporality - one that (for many but not for all) stays in finitude, stopping away from eternality. I call this perennialism. ${ }^{35}$ In this concluding section I will

34 More specifically, some inspiration for a viable neo-idealism will be found, as I see it, in some version of personalist, rather than absolute, idealism, notably the Boston or (American) Personalism active at Boston University c. 1890-1940.

35 As to the term perennialism, one precedent is its use to name the view that mystical experiences of the pure consciousness type are not constructed by consciousness but are outside consciousness of time, q.v., The Problem of Pure Consciousness Mysticism and Philosophy, edited by Robert K. C. Forman (New York, Oxford: Oxford University Press 1990), 2-4. As an approach to time, Nicholas of Cusa's notion of an unfolding present in De Docta Ignorantia 2.3.106 has influenced me. As theory of history, the work of Max Weber includes perennialist approaches, as does Marcel Gauchet's The Disenchantment of the World: A Political History of Religion (Princeton: Princeton University Press, 1997) (Le désenchantement du monde (1985). Lorenz and Bevernage Breaking Up Time, 156-175, suggests a continuous present as the requisite diachronic addition to synchronic thinking; see also Jonathan Gorman, "The Limits of Historiographical Choice in Temporal

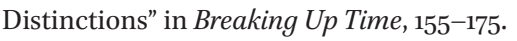


show how perennialism is an historical-theoretical way of stepping onwards to an idealist form of time-breaking.

The issues of the human relationship to divinity, earth and cosmos; of unity, multiplicity, and participation in the constitution of reality; of inwardness and externality, permeability and immunity; of the conditions of existence that constitute knowledge, thought, and experience; and, most profoundly, of what it is to be good and just, to do right and justice, and not to do what is wrong and evil - these issues are rooted for philosophers at the level of ontology as pure forms of idealism and materialism, as two paradigms that altering thought employs to explain these problems in a crazy pattern of different ways. They are not pests to be dissolved but are, instead, perennial matters in the human encounter with the universe. The level of ontology, as the dynamic between idealism and realism, is a high-order and rather full expression of this, although these-isms are highly flexible. Ontology in this sense just is this high-order way of grasping these moral matters and controverting or narrating them, and the practice of ontology is twisting idealist or realist notions in order to organize sets of rational responses to these matters.

For just this reason ontology is mere ontology: its squadrons of doctrines are less important than the moral considerations that they were intended to help resolve. Final disposition of ontological questions is always less important, if choice must be made, than answering the question of the next right thing to do. Moral matters have their ground beyond ontology in the diachronesis of moral life, which is not an exact science, progressing from truth to truth. This history is more like Benjamin's angel of history: often retreating, despairing, but not surrendering.

Moral life is marked by the diachronic accumulation of experience amid transitoriness. These rub against one another as persons respond to their feelings of moral obligations, as the amount of pressure they exert on actors at different historical moments rises and falls. This is the historical experience of moral life. Human self-awareness does not lie inertly ready like a body of propositions or facts in a text. It grows from and with the accumulation of memory, that is, past, or, broadly, historical experience. We quickly busy ourselves in the world we are thrust into or find for ourselves - an office, a boarding-house, a solitary or social compulsion, a family, a civilization, fandom, for example - in which the dramaturgy becomes tragedy, comedy, melodrama, and farce. The rational faculty has little part to play when the air is all filled with cries for help, the arguments about which are the selfsame cries subsequently shaped by logic used as the lathe on which to turn them. Initiating the span of the experience of obligation, through which we try to figure out whom to help and what to do, is required but often unmanageable in the prevailing 
circumstances. As objects and events in the world come to our attention, they do not simply "determine" moral life. Their power over the will is far too simple to account for our butterfly's flight from material determinants in search of moral force. As complex as they are, so much more are we. Not only will we make our moral values by use of facts and things, we make them while making facts and things - in our artefacts, narratives, and actions. This transmutation goes on unceasingly, at each moment re-calibrating the importance of some issues with respect to the others. Moral life always existed since it commenced, as a loud inward struggle, the bright ribbon of which connects the world to us and our knowledge to moral assent. Like physical life, moral life is always a going concern, a trans-historical and trans-tribal effort of humanity amid the unceasing forces of nature. This effort to take in outward things and events into moral knowledge, which both requires and nourishes moral agency, is the living tissue of moral life. ${ }^{36}$

Bearing in mind this kind of diachronic development, we are in a position to see that moral philosophy is, at least in part, an object of historical inquiry and that we must dedicate a part of the work of history to the study of moral experience, obligation, and life. This historiography endeavors to understand the moral worlds of historical actors in terms of perennial moral issues, whether actors are guided by rules, or results, or other principles. These issues include universal (impartialist) or local (partialist) notions of the good, self-care versus care for others, short-term and long-term points of view, and the individual versus the societal goods; and the careful consideration of the relationships among beliefs, reasons, desires, and motives. Following this pattern, the historian will find a good, often fresh, position with which to account for instances, and their opposites, of things people value: friendship, loyalty, forgiveness, valor, love, justice, education, divine worship, and many other goods.

Because its concern is the shaping of moral thought (and of knowledge more generally) and its impact on historical events, perennialism, as an anchor

36 The part that philosophical ethics can play is also well due for enrichment by an encounter with meaning in historical time. The philosopher Talbot Brewer in his important book, The Retrieval of Ethics, broke this ground in forcefully criticizing the static, uncontextualized form of contemporary meta-ethical argument. He calls this "propositionalism." Propositions in this discourse tend to require completed activities in order to set terms for evaluation, or else it is hard to form propositions; and likewise they tend not to address the progressive understanding by agents as their circumstances change. The philosophical work then tends to respond to propositions rather than to actions. Brewer calls this "the evaluative outlook: a cultural prejudice in favor of production-oriented concepts of actions makes nonsense of ethics." The result is the impoverished discourse of much of contemporary philosophical ethics and meta-ethics.

JOURNAL OF THE PHILOSOPHY OF HISTORY 12 (2018) 5-26 
for the historiography of moral experience, necessarily tends towards idealist ontology. If materialist ontology were true, historical events would be deceased in the natural way: they could have no life, and we could not change the past in such a way as to alter ourselves in orientation towards the future. Materialism or the casual materialist appropriation of phenomenology is not adequate to this. If historians wish consistently to regard the past as available to us to be rethought as part of our future, their work must be idealist at least in some measure. This availability is precisely the aim of breaking up time. It bridges merely factual history of the past and time re-lived in the horizon of the future and the present. ${ }^{37}$ In this way time-breaking, within idealism or idealist-inflected phenomenology, is part of an historical-theoretic approach to the perennial moral conflicts of facts and values, explanation and understanding, automation and agency, ratio and charisma.

A perennialist historiography interprets historical situations as the recurring moral struggles of human persons and collectives. It regards these struggles as something other than a moment in the sequence of natural causes that comprise natural history. Its different character is that of the person called upon to make choices in moral dilemmas. In this regard the person is like nothing else; any and all entities that make moral choice are persons. This impudent circularity, defying ontology, perhaps as galling as solipsism, takes its brass and guff from the single presumption that each of us makes choices of moral consequence, this assurance being the sole yet sufficient validating argument for the limitations of ontology against a necessary manner of thought with which our minds must link it but which we are obliged to contain and limit, deferring to it and also rejecting it. The sphere in which we study deference to principles, abstract or particular, and rejection of them, is one of the meanings of the word history. Historians in perennialist mode study this agonism throughout its reiterations in successive circumstances. Perennialism uses this inconstant and unhappy union of ontology and ethics - logic and circumstance - which this one kind of historiography takes as its theme because it is the story of every historian and of every person in so far as she is an historian who pro tanto has the moral situation of human persons in her present conscious awareness. ${ }^{38}$

37 Paul Ricoeur's exposition of historicity approaches this point of view from a phenomenological perspective, set in relation to death, following Heidegger, in Memory, History, Forgetting, translated by Kathleen Blamey and David Pellauer, 376-382 (Chicago: University of Chicago Press, 2004).

38 These considerations raise philosophical problems that, though it is not possible to address in this paper, perennialism has the resources to address or that are part of the larger framework with which these considerations are allied, including, among others, 
For the perennialist, the re-appearance of the originary in later times serve as a simple proof that the human person is riven from within, rocking between habits and desires for adventure and change, fissiparous by nature, a part of universal ceaseless change. If this is so, the mutability itself is mutable. It reveals its contrary: this is the ancient and very widespread intuition at the gate of the philosophia perennis. Understanding human affairs as moral experience is necessarily an ideal understanding because it requires a ground of morality - whichever kind of morality one chooses - that has never yet been found to exist in nature and that is distinctly human. Any claim to find it in nature shows its own historicity, immediately subverting its pretense to a neutral character.

What in the end is breaking up time for beyond accounting for facts or in analyzing deeper or broader historical structures? If we are to think all the way to the end of the problem, its value is its provision of the possibility - in the face of attendant risks, working with imperfect answers to problems that never go away - of giving our attention to moral issues that persist into the period of time in which we come to give them our attention.

the unitary self, the immune self, basic patterns in the relations of individuals and collectives, the nature of historical change, what revolutions are or are not, and how historical inquiry can particularize the object of its study and also account for longer and deeper structures in human affairs. 